\title{
STATE PROTECTION UPON ADOLESCENT VICTIM OF INCEST RAPE THROUGH GENDER LENS
}

\author{
Elita Rahmi, Elly Sudarti \\ Faculty of Law, Jambi University \\ Elitarahmi79@yahoo.co.id \\ elly.sudarti@yahoo.com
}

\begin{abstract}
The state obligations to fulfill and protect the rights of adolescent victim of incest rape post-abortion and other rights have not been exercised during the legal process of investigation until court verdict as it is indicated that the adolescent victim is unfairly detained without due process for illegally practicing abortion. This occasion indicates that the law is being unfair towards the adolescent victim without considering the precondition which inevitably forces the abortion. This article scrutinizes such case of MuaraBulian county in which the local court's verdict No. 5/Pid.Sus.Anak/2018/PN.Mbn did not accommodate the substantive justice which take stand of the rights of adolescent victim of incest rape. The verdict indicates that such court verdict does not express gender sensitivity to the right of adolescent female victimof incest rape to which the state is obliged to fulfil and protect.
\end{abstract}

Keywords: State Protection; Adolescent Victim; Incest Rape; Gender

\section{Introduction}

Incestuous sexual act is condemned in any part of the world. The law, along with every elements of moral, religion, and social order, must work together in order to ensure the prohibition and the eradication of such morally corrupt act. Often such incestuous sexual act is coerced from a person with superior position to its inferior such as a parent to its child, an older sibling to its younger, older relative to its younger one. Rape is commonly found in incestuous sexual act in which the child or adolescent victims are powerless to counter or object to such coercion from their superior relative due to the familial culture of superiority ties to age and generational gap. Therefore, the state is obliged to fulfill and protect the rights of the victim of incest rape such rights to; recover from physical and non-physical damage, legal protection from further possible retaliation by the perpetrator, and protection from unfair treatment by the state and society.

Sexual violence against women and children occur indiscriminately throughout Indonesia. Even in the era of rapid technological progression, the rate of which seems to be increasing exponentially. In Jambi province for instance, the exponential increase of internet surfing activities in which the borderless and unregulated space of advanced information technology has somewhat been contributed to that of sexual violence and harassment against women and children. This indicates that the government must be very committed in enacting repressive and 
preventive efforts against the prominent sexual violence and harassment. Not only that, the government must also take consideration of the damage done to the victims to which the recovery process to mend such damage and trauma are essential. The legal system and its enforcement institutions must also take such problem into account as to the treatment towards the victim during the legal process. Extensive legal protection and recovery treatment are essential in order to build a countermeasure system towards sexual violence which could harm further generations, especially regarding gender justice.

In 2017, the National Commission of Child Protection (KPAI) reported that there are 350.472 cases of sexual violence (physical or non-physical) occurred in Indonesia ${ }^{1}$. Overall, the rate of sexual violence and harassment towards women and children are increasing exponentially in Indonesia. As of June 2018, there have been 150 cases of various gender-related crimes in which 67 cases of sexual harassment, 22 cases of underage sodomy, 29 cases of marital violence, and 2 cases of human trafficking. In Jambi province, the local governmental body for Population Control and Protection to Women and Children reported that there have been 105 cases of sexual violence and harassment towards women and children. The Sarolangun Regency reported of 60 cases $^{2}$. Such amount of reported cases indicates that Indonesia has been in an emergency state of sexual violence towards women and children.

A study is needed for the law enforcement institutions in order to raise their gender sensitivity and awareness through which the question, on whether women and adolescent victims of sexual violence are the perpetrator or the victim, must be scrutinized. In the Law No. 39/1999 on Human Rights -the Human Rights Act-, pregnant women and children are included as vulnerable groups to which the law enforcements in Indonesia must give attention. Psychological approach, witness protection, and advocacy are parts of the right of the victim on which the government must take immediate and effective actions.

After all, only the judicial system to which these victims rely their search for justice. However, the fact tells otherwise as such victims often experienced discrimination and even unfair treatment from the law enforcement. Such occasions of which are shown in the case of Baiq Nuril Maknun in Mataram, Lombok and the case of WA in Muara Bulan, Jambi.In

\footnotetext{
1 Dany Permana, "PSI Puji Keputusan Pengadilan Jambi Bebaskan Korban Pemerkosaan," Tribun News, last modified 2018, https://www.tribunnews.com/nasional/2018/08/28/psi-puji-keputusan-pengadilan-jambi-bebaskankorban-pemerkosaan.

2 Fadly Fadly, "2018, Terdata 105 Kasus Kekerasan Dan Pelecehan Terhadap Anak Dan Perempuan Di Jambi," Tribun Jambi, last modified 2018, https://jambi.tribunnews.com/2018/10/16/2018-terdata-105-kasus-kekerasandan-pelecehan-terhadap-anak-dan-perempuan-di-jambi.
} 
Indonesia's law enforcement system, these cases are worth of critical scrutiny because the court process still lacks of justice sensitivity to gender matters. The case of Baiq Nuril Maknun, or Nuril she called, is notoriously known as the example of miscarriage of justice by the court. Nuril was a high school teacher and also a victim of sexual violence and intimidation by her principal. She then tried to retaliate by recording the call from her principal in which Nuril was insulted and threatened. The call record was then leaked to peers and eventually the higher authority who later discharged the principal. The principal then retaliated back and reported Nuril to the police for violating the article 27 paragraph (1) of the Information and Electronic Transaction Act which prohibits a record distribution of sexual indecency. The local court of Mataram ruled that Nuril was not guilty. However, this court verdict was then overturned by the Indonesian Supreme Court, hence convicted as guilty. Shewas then punished for six months of prison term and 500 million rupiah of fine.

Another similar case also occurred in the local court of MuaraBulian, Jambi whereby an adolescent girl named WA was convicted for 40 days-late abortion, along with her mother as accessory. The problem is, WA was pregnant as a result of rape by her older brother. This case has taken the international attention to such occurrence of law's injustice towards an adolescent victim of rape. Although this verdict was later overturned by the High Court of Jambi, the decisions of the law enforcement (the police and the public prosecutor of MuaraBulian) and the court have appaled the public. This shows that both the law enforcement and the justice systems in Indonesia have not been raising gender sensitivity and championing gender justice even though there is a legislation for that regard. In the Law No. 13/2006 on Witness and Victim Protection, the Law No. 11/2012 on Juvenile Criminal Justice System, and the Law No. 7/1984 on the Ratification of the Convention on Elimination of All-Forms of Discrimination Against Women (CEDAW), it is emphasized that women deserves a fair treatment before the law for being either a victim or a perpetrator. Yet otherwise, the current justice and legal systems in Indonesia have not been manifesting such spirit into their perspective and practice, thus resulting in a hostile climate of those systems which tend to discriminate women and children and disregard their rights.

Moreover, sexual violence is a multi-faceted issue in which the details of a sexual violence should not only be understood as retributive to the perpetrator but also restorative to the victims. The lack of awareness of the law's function to "restore" the damage done to the victim as a part of justice is the underlying problem of the miscarriage of justice in the cases of Nuril and WA. 
Moreover, the law enforcement system tends to disregard the specific nature of sexual violence that is 'hidden' or 'domestic' as such violence occurs in domestic places such as family, romantic relationship, workplace, and friendship which undermines the urgent of sexual violence to be reported as the victim often fears retaliation and backlash from not only the perpetrator but also from the social stigma ${ }^{3}$.

Various laws have been presented by the State to address the issue of sexual violence against women and children. Government policy, in terms of regulation of protection of women and children is quite a lot but the regulation is weak in upholding and understanding the community, parents, government and the country itself, this is evidenced by the many cases of sexual violence for women and children punished by judges without considering matters outside the law, do not consider the psychological aspects of the child and eventually develop into street children as a choice of life. Protection of women and children victims of sexual violence, especially incest is interesting to study because incest is a social phenomenon that cannot be ignored by the state, law enforcers as part of state power must provide solutions through legal discovery by judges who guarantee victims' rights for their survival in the future.

The first thing that is expected from the judges is gender sensitivity, as a basic attitude to empathize with the issue of discrimination that women must accept and live as members of the community. In this perspective, the main key for resolving victims' cases, in this case women, is to enrich the quality of the character of judges with adequate knowledge of gender as a social construct that will assist the justice process.

With regard to the above, this study examines the child victims of incest rape in a gender perspective. There are 3 (three) fundamental issues when discussing gender issues, namely; (1) State Obligations; (2) Principle of Non-Discrimination and; (3) Substantive Justice). The problem is whether these three principles have been implemented in a real way at each stage of the examination of cases of child rape victims. On this issue the researchers formulated the following problems: (1) How to deal with children who are victims of incest rape in investigations; (2) How do children who are victims of rape incest in prosecution ?; (3) How are children victims of incest rape in court?

\footnotetext{
${ }^{3}$ Moerti Hadiati Soeroso, Kekerasan Dalam Rumah Tangga Dalam Perspektif Yuridis-Viktimologis (Jakarta: Sinar Grafika, n.d.).
} 


\section{Research Method}

This article is a case-study ${ }^{4}$ to the case of unfair conviction of WA in MuaraBulian with an accentuation of approach of gender-based perspective ${ }^{5}$. A research based on gender perspective scrutinizes three fundamental matters that are: 1) state obligation; 2) equality before the law, and 3) non-discrimination. Research on gender and child issues is sensitive, especially the issue of sexual violence, is still considered very private because it is related to family disgrace, especially in cases of incest or blood relations, a persuasive approach is needed so that the training atmosphere of the case can be explored in depth. The data will be focused on literature data such as court decision, legislative drafts, and other related legal documents. As supportive data, the research have also taken testimonies from direct interviews with corresponding sources such as the defense lawyer of adolescent victim of sexual violence, activists and social workers of Jambi's Orphanage and Victim Safehouse which is managed by the Ministry of Social Affairs of Indonesia.

\section{Results and Discussion}

\subsection{Case Chronology}

An adolescent woman named WiwinAstika (WA), age of 15 years old, was lived at Pulau Village, Muara Tembesi County, Batang Hari Regency. She was a third grade student of Madrasah Tsanawiyah, an Islamic-based middle school. WA was a victim of rape did by her older brother (17 years old). A person's life cannot be separated from the social structure that surrounds him as long as he is part of the community members ${ }^{6}$. Likewise the social structure of the life of the child of the rape victim. WA The child of the rape victim is the victim of the divorce of his parents (his mother Asmara Dewi and his father Efendi Kadir), victims of low religious understanding, and victims of poverty. After the divorce, her mother was a single breadwinner, working as a rubber cutter farmer, who required her to go to work at 5:00 a.m. and go home at 5:00 p.m. All day after school WA and AR spend their time at home together. They occupy a wooden house, where the walls of the room are not so tight, so that the activities of people in the room can be seen, WA rooms do not have doors. Inadequate housing conditions

\footnotetext{
${ }^{4}$ Creswell JW, Qualitative Inquiry and Research Design: Choosing among Five Traditions, SAGE Publications, California, 1998, p. 134

${ }^{5}$ Caroline Moser, Gender Planning and Development: Theory, Practice and Training (London and New York: Routledge, 2012).

6 Andi Tyas Surya Nugraha, "Represi Terhadap Incest (Kajian Terhadap Kasus Di Kabupaten Aran Pandang)," Jurnal Ilmiah Sosiologi Agama 9, no. 2 (2015): 94-95.
} 
and lonely conditions in the house provide opportunities and opportunities for AR to rape WA. As for the characteristics of sexual violence: (1) Conducted by most close people who are well known to the victims; (2) Place of occurrence anywhere, anytime, and by anyone ${ }^{7}$. Even in other studies showing sexual violence is a crime that is universal and can occur anywhere regardless of age and sex, although most occur under the age group of 18 years and are female ${ }^{8}$. The case of WA children who are victims of incest rape shows that children no longer have a safe place at home, sexual violence is actually carried out by family members and those closest to the child. In this position, children are in a very weak position to reject, resist or complain of sexual violence they experience.

WA is convicted in case No. 5 / Pid. Sus-Anak / 2018 / PN Mbn is a 15-year-old child who is charged with committing an abortion offense set in Article 77A in conjunction with Article 45A of Law No. 35 of 2014 concerning Amendment to Law No. 23 of 2002 concerning Child Protection. The child is still 15 years old, has a pregnancy due to intercourse which is carried out by his own siblings who are still 17 years old, who are also prosecuted criminally by case number No. 4 / Pid. Son-Child / 2018 / PN Mbn who on the same date July 19, 2018 was sentenced to 2 years in prison due to the intercourse.

WA The child of the rape victim was charged with a single indictment of Article 77A in conjunction with Article 45A of Law No. 35 of 2014 concerning Amendment to Law Number 23 of 2002 concerning Child Protection in conjunction with Article 55 paragraph (1) of the Criminal Code for committing an abortion to a pregnancy he conceived as a result of rape by his own siblings. The indictment imposed on the child (WA) by the Public Prosecutor was the single charge of the child having an abortion along with his mother named Asmara Dewi who was also presented as a Witness.

During the trial process, WA was detained with details as follow:

1. WA was initially detained for 7 days which then extended for other 8 days (May $31^{\text {st }}$ June $14^{\text {th }} 2018$ )

2. The detainment was then suspended for 15 days (June $8^{\text {th }}-$ June $22^{\text {nd }} 2018$ )

3. WA was detained again after the suspension without any explanation and due process for 7 days (June $23^{\text {rd }}-$ July $7^{\text {th }} 2018$ )

\footnotetext{
7 Dwi Hapsari Retnaningrum, "Incest Sebagai Bentuk Manifestasi Kekerasan Terhadap Perempuan,” Jurnal Dinamika Hukum 9, no. 1 (2009): 19-20.

8 Mohammad Tegar Indrayana, "Profil Kasus Kekerasan Seksual Terhadap Perempuan Dan Anak Yang Diperiksa Di Rumah Sakit Bhayangkara Dumai 2009-2013,” Jurnal Kesehatan Melayu 1, no. 1 (2017): 9-13.
} 
4. The detention to prosecution process which took 5 days with another extension of 5 days detainment (June $23^{\text {rd }}-$ June $29^{\text {th }} 2018$ )

5. The detention was extended for investigation matters in the court for 10 days and 15 days extension (July $5^{\text {th }}-$ July $29^{\text {th }} 2018$ ).

During the investigation, WA had been provided with a pro bono lawyer named Damai Idianto. In the process of examining the case, the verdict stated that the child of the rape victim received legal assistance as of July 9, 2018 based on the Letter of Determination Number 5 / Pen.Pid-Anak / 2018 / PnMbn, accompanied by DamaiIdianto, S.H. Whereas the inspection process has been going on since May 31, 2018, and the hearing at the court of the first hearing was held on July 9, 2018;

During the trial the child was indicted and prosecuted, that the child of the rape victim committed an abortion on May 22, 2018 by first telling the witness Asmara Dewi that her stomach was sick, but the child of the rape victim only stated that her stomach was due to menstruation, then witness Asmara Dewi giving wind oil to the child of the rape victim after Witness Asmara Dewi cut the rubber. After greasing the wind, Witness Asmara Dewi, who was the mother of the rape victim, asked the child of the rape victim whether her stomach was still sick. Then the child of the rape victim stated that his stomach was still sick, then Witness Asmara Dewi made the juice of turmeric mixed with salt for the child who was the victim of rape. At 6:00 p.m. in the afternoon, the child of the rape victim sorted out his stomach in his own room, and found the baby in the womb coming out, but did not cry, then the rape victim cut the umbilical cord of the baby and then the rape victim found a baby the child had died, then the Child Victim of rape bandaged the baby with a white headscarf and a brown table cloth and put the wrapped baby under the bed. The next morning, when Witness Asmara Dewi or the child mother of the rape victim went to work, the child of the rape victim brought the baby's corpse to an oil palm near the house and the child of the rape victim dug the not too deep ground and the child of the rape victim into the hole then The child of the rape victim returns home.

In the process of examining the case, the verdict stated that the child of the rape victim received legal assistance as of July 9, 2018 based on the Letter of Determination Number 5 / Pen.Pid-Anak / 2018 / PnMbn, accompanied by DamaiIdianto, S.H. Whereas the inspection process has been going on since May 31, 2018, and the hearing at the court of the first hearing was held on July 9, 2018; 
On May 30, 2018 at around 1:30 a resident, Witness Ansori bin Yusup, found the baby's body wrapped in a white headscarf and brown tablecloth which he then reported the discovery to Witness Syukri Bin Sa'I. The child of the rape victim was then arrested on 30 May 2018, and immediately served a period of detention from 31 May 2018 to the time of the verdict. The child of the rape victim was then charged with a single indictment of Article 77A in conjunction with Article 45A of Law No. 35 of 2014 concerning Amendment to Law Number 23 of 2002 concerning Child Protection in conjunction with Article 55 paragraph (1) of the Criminal Code for abortion allegedly committed by a child of rape Victim who also allegedly carried out with Witness Asmara Dewi who was the Mother of the Child Rape Victim.

In the process of verification at the trial, it was obtained the fact that the child of the rape victim who had an abortion was not assisted by Witness Asmara Dewi, who was the mother of a child who was a rape victim. But on this basis, the Public Prosecutor on Wednesday, July 18, 2018 continued to prosecute the Children of Victims of Rape with the same article with the charges namely Article 77A in conjunction with Article 45A of Law Number 35 Year 2014 concerning Amendment to Law Number 23 Year 2002 concerning Child Protection in conjunction with Article 55 paragraph (1) 1st Criminal Code with a sentence of imprisonment for 1 (one) year imprisonment and a fine of Rp. 800,000,000.00 (eight hundred million rupiah) Subsidized work training for 3 (three) months. For the prosecutor's demands, only a day later, on July 19, 2018 the judge handed down the verdict of imprisonment for 6 months in prison and job training for 3 (three) months, after the verdict the Child Rape Victim remained detained.

On Thursday, July 26, 2018, this case was appealed for by the Children of Victims of Rape and on July 27, 2018 the deed of appeal was notified, on July 27, 2018 the appeal memory was sent, the stipulation of the trial day was set for Wednesday, August 1 2018. On Thursday August 22018 counter appeal from the Public Prosecutor was received by the Jambi High Court. WA held detention at the appeal level from 26 July to 4 August 2018. Then the detention was suspended by the Panel of Judges of the High Court from 31 July 2018. Decision of the High Court Number 6 / Pid. Sus-Anak / 2018 / PTJMB dated 27 August 2018, fill the High Court's decision is to "release the child from all lawsuits". The case of WA when the research was conducted by WA was placed in a shelter house, and the WA case was in the process of appeal. 


\subsection{The State of Adolescent Victim of Incest Rape during Investigation Process}

WA is a victim of incest rape who is imprisoned for practicing an illegal abortion. In the juvenile justice process, even though the child is undergoing a judicial process, the child continues to obtain his rights as a child protected by the state. Child rights of children as victims as well as perpetrators include the right to obtain legal assistance, recovery from trauma and psychosocial rehabilitation.

Judging from the criminal justice system workflow, a series of processes starting from Investigation, prosecution, examinations in courts and prisons. "Investigation is police action to find facts or uncover crimes by questioning who, what, where, how and why the crime was committed. Investigation is the process of gathering evidence and materials to find a clear picture of a violation" ${ }^{9}$. The investigation phase is a gateway in the criminal justice system in Indonesia. "The judicial process of cases of sexual violence against women usually begins with reporting the occurrence of a crime to the police, then following up the report by conducting an investigation to determine whether or not an investigation can be carried out"10. The investigation phase is a decisive process on whether or not a case is delegated to the prosecutor's office.

In the Criminal Justice System the Child is known to have child investigators, child public prosecutors and child judges. "This legal officer is authorized by law to handle child criminal cases according to the level of each examination. It is expected that case audits take into account the interests of children " ${ }^{11}$. Child investigators at the Polres level are under the PPA Unit. Batang Hari Police Resort (Polres) currently there are 5 (five) child investigators consisting of 3 (three) male and female investigators 2 (two) female investigators. "The spirit of the PPA Unit should be the defense of women and children who are victims of sexual violence, so there must be different procedures and not general procedures that apply. Questions must be avoided that hurt the victim's heart. Handling cases of victims of sexual violence cannot be compared to other cases " ${ }^{12}$. In the case of WA, the PPA Unit in carrying out its duties and authorities does not work as expected.

\footnotetext{
9 Aryanto Sutadi and et. al, Diskresi Kepolisian; Dalam Tinjauan Hukum Dan Implementasinya Di Lapangan (Jakarta: Penerbit Kompolnas, 2013).

${ }^{10}$ Lisa Wulansari, ed., Penanganan Kasus-Kasus Kekerasan Terhadap Perempuan Di Lingkungan Peradilan Umum (Jakarta: Komnas Perempuan, 2009), 65.

${ }^{11}$ Gatot Supramono, Hukum Acara Pengadilan Anak (Jakarta: Djambatan, n.d.).

${ }^{12}$ Wulansari, Penanganan Kasus-Kasus Kekerasan Terhadap Perempuan Di Lingkungan Peradilan Umum, 70.
} 
In the case of WA, the country should be present from the start that WA is a child who is a victim of rape that must be protected. The state (police) can use discretionary measures not to continue the case of child victims of rape in the legal sphere. Police authorities are given the law to act in special situations in accordance with the judgment and conscience of the agency or the official itself $" 13$. This act of discretion must be seen as an attempt to find a solution that does not cause new problems, including injustice. Unfortunately this discretionary action was not used by investigators in handling this case, so the case was delegated to the District Prosecutor's Office Muaro Bulian.

As suspects, law encounters underage have rights. Law No. 11 of 2012 regulates Article 3, as follows: Every child in the criminal justice process has the right, at the stage of investigation, the child has the right, including:

a. Treated humanely by observing needs according to their age;

c. Obtain legal assistance and other assistance effectively;

g. Not arrested, detained or imprisoned, except as a last resort and in the shortest amount of time;

j. Obtain assistance from parents / guardians and people trusted by children;

k. Obtain social advocacy;

In Law Number 11 of 2012, Article 3 letter (a). Declare: Treated humanely by observing needs according to their age. get spiritual and physical care, get an education. During the investigation process to court decisions, WA education was neglected. The WA case was revealed in May 2018, at that time WA had finished undergoing the National Final Examination, WA should have continued her education to the level of High School (SMA). It is the state's obligation as stipulated in Law Number 7 of 1984 Article 10 paragraph (e), to administer the continuation of WA education, but the state ignores WA's education rights.

Furthermore, it is in accordance with the mandate of Article 12 paragraph (2), Law Number 7 of 1984 concerning Ratification of the Convention concerning the Elimination of All Forms of Discrimination Against Women. The state's obligation is to provide appropriate services related to the period after delivery by providing free services where necessary, and providing adequate nutritious food during pregnancy and breastfeeding. The WA abortion incident took place on May 22, 2018, WA was arrested on May 30, 2018 then detained against WA on May 31, 2018. Detention occurred after 8 days after the abortion, meaning WA was still

\footnotetext{
${ }^{13}$ H. Bayley David, Police for the Future (Polisi Masa Depan) (Jakarta: Cipta Manunggal, 1994). 
in a period of fanfare. Rape of WA that caused her to become pregnant until she had an abortion. This unsafe abortion occurs because of an unwanted pregnancy. The state has an obligation to protect WA's reproductive health, the state should provide free services where necessary, and provide adequate nutritious food. As a rape victim WA should get the right to get a safe abortion treatment that is carried out in accordance with the Health Law, which is carried out through a pre and post-counseling process with a competent counselor (Article 75 paragraph (3) Health Law). In the case of WA, the rights of these victims are completely unfulfilled, precisely what happens when WA is criminalized by accusations of having an abortion is not according to the procedure. WA's position as a child who is traumatized should be helped to access his reproductive health rights.

In Law Number 11 of 2012, Article 3 letter (c), Obtain legal assistance and other assistance effectively. Presenting legal assistance and other assistance effectively to assist children is the state's obligation. There are indications that there is legal assistance that is ineffective and not cryptic for children who are victims of rape at the stage of the investigation. If the legal assistance received by the child of the victim of rape is effective and credible, then the legal advisor should ask for the legal release of the child of the rape victim.

In Law Number 11 of 2012, Article 3 letter (g), Not arrested, detained or imprisoned, except as a last resort and in the shortest time;

WA children of victims of incest rape should not be detained. WA should be secured at the Protection House, but on the contrary since the investigation into incest, WA cases of child victims of rape were detained, this is contrary to Article 3 letter g of Law Number 11 of 2012. WA rape victims are detained from the stage of investigation, prosecution and examination in court . Based on Article 30 to Article 35 of Law Number 11 of 2012 concerning the Child Criminal Justice System, the detention period for children facing the law is determined as follows: arrest 1 (one) day, detention stage of investigation for 7 (seven) days can be extended 8 (eight ) Anniversary amount of 15 (fifteen) days. The detention of the 5-day long prosecution phase can be extended by 5 (five) days in the amount of 10 days. The trial phase has a length of detention of 10 (ten days can be extended 15 (fifteen) days, so the amount is 25 (twenty five) days.

Based on Article 30 of Law Number 8 of 1981 concerning the Criminal Procedure Code (KUHAP), if the detention period is carried out by a suspect or the defendant is invalid, then the suspect or defendant has the right to request compensation, in Article 33, Article 34, Article 35 
of the Law Number 11 of 2012 concerning the Juvenile Criminal Justice System, if the detention exceeds the regulated period, the child must be issued by law. In this case, even though the detention period at the stage of the investigation has exceeded, the child of the rape victim was not released from detention for the sake of law, this indicates that there is ineffective legal assistance for the Child Rape Victim. If the legal assistance received by the child of the victim of rape is effective and credible, then the legal counsel should ask for legal release of the child of the rape victim, the legal counsel can file a claim for compensation for illegitimate detention and can be examined at the trial. Presenting legal assistance and other assistance effectively is a state obligation.

Since the beginning, children have not received assistance from parents / guardians and people who are trusted by children, as well as social advocacy. There is no assistance or social advocacy that causes victims' rights to be neglected. Ironically, the parents (mother) were even made suspects to participate in the abortion.

In Law Number 11 of 2012, Article 3 letter (j), Obtain assistance from parents / guardians and people trusted by children; Article 3 letter (k), Obtain social advocacy; Since the beginning, children have not received assistance from parents / guardians and people who are trusted by children, as well as social advocacy. There was no assistance or social advocacy, causing victims' rights to be neglected and ironically, their parents (mothers) were even made suspects to participate in abortions. Whereas in this case, the role of social research is minimal, community research reports are only related to normative matters which do not explore the background of criminal acts, community research only mentions the following: (a) Crime committed by the Client threatened with imprisonment of 7 (seven) years; (b) The client wants to continue his education so that his dream of becoming a teacher is achieved; (c) The Client promises not to repeat his actions or other criminal acts; (d) The social environment where the Client's parents and siblings live is quite good and conducive to the Client (page 19 verdict verdict 5 / Pid-Son / 2018 / PN Mbn). Whereas in the community research report, it was not excavated at all that the child of the rape victim had an abortion due to the pregnancy he suffered because of the rape he suffered for 9 times.

Based on the explanation that has been stated, WA children who are victims of incest rape have been discriminated against in investigations, investigators tend not to side with women victims of rape by assigning rape victims as abortionists, regardless of the cause of abortion. State obligations in fulfilling WA rights Victims of rape for post-abortion services are not 
obtained as mandated in Law Number 7 of 1984 Article 12 paragraph (2), as also stipulated in the Health Act Article 75 paragraph (3). The state's obligation in fulfilling the WA rights of victims of rape does not get their rights as stipulated in Article 3 letters (a, c, g, j, k) of Law Number 11 of 2012 concerning the Child Criminal Justice System.

\subsection{The State of Adolescent Victim of Incest Rape}

The experience of women in the prosecution process took place in two statuses, the first being status as victims whose interests were represented by the Prosecutor. Secondly, the status as a defendant must face the Prosecutor as a public prosecutor. While the only institution that prosecutes a general crime is the prosecutor's office ${ }^{14}$. Sexual violence against children occurs in many forms, which can be when a child is made uncomfortable by a sexual offender, even by indirect sex, when a child is forced, cheated or threatened with sexual contact ${ }^{15}$.

Child sexual crime is a form of child torture where older adults and adolescents use children for sexual stimulation and child sexual crimes have traumatic impacts experienced by children who are victims of sexual violence so difficult to recover ${ }^{16}$. Sexual crime against children is a national disaster for the Indonesian people, sexual crimes damage the next generation of the Indonesian nation ${ }^{17}$.

The handling of child rape victims at the prosecution stage is a continuation of the investigation. Since the investigation began there was an obligation for the investigator to notify the public prosecutor through the Notice of Commencement of Investigation (SPDP). Since the investigation there has been a coordination relationship between the investigator and the public prosecutor. At the time of the title of the case between the investigator and the public prosecutor there was no progress on gender issues, the issue of victims, and the fulfillment of victims' rights. The case title does not give meaning to the authority of the public prosecutor to stop the prosecution. The condition of WA in the investigation can be said to be the same at the stage of the prosecution. The principle of state obligations, the principle of substantive justice and nondiscriminatory principles is not at all received attention at the prosecution stage.

\footnotetext{
${ }^{14}$ Wulansari, Penanganan Kasus-Kasus Kekerasan Terhadap Perempuan Di Lingkungan Peradilan Umum, 85.

${ }^{15}$ Syarifah Fauzi'ah, 'Faktor Penyebab Pelecehan Seksual Terhadap Anak,” Jurnal An-Nisa' IX, no. 2 (2016): 82.

${ }^{16}$ Siti Hikma, "Mengantisipasi Kejahatan Seksual Terhadap Anak Melalui Pembelajaran 'Aku Anak Yang Berani Melindungi Diri Sendiri,"” Jurnal Sawwa 12, no. 2 (2017): 189.

${ }^{17}$ Ratih Probosiwi and Daud Bahransyaf, "Pedofilia Dan Kekerasan Seksual: Masalah Dan Perlindungan Terhadap Anak," Jurnal Sosio Informa 1, no. 1 (2015): 30.
} 


\subsection{The State of Adolescent Victim of Incest Rape during Trial Procedures}

In the process of verification at the trial, it was obtained the legal fact that the child of the rape victim who had an abortion was not assisted by Witness Asmara Dewi, who was the mother of a child who was a rape victim. But on this basis, the Public Prosecutor on Wednesday, July 18, 2018 continued to prosecute the Children of Victims of Rape with the same article with the charges namely Article 77A in conjunction with Article 45A of Law Number 35 Year 2014 concerning Amendment to Law Number 23 Year 2002 concerning Child Protection in conjunction with Article 55 paragraph (1) 1st Criminal Code with a sentence of imprisonment for 1 (one) year imprisonment and a fine of Rp. 800,000,000.00 (eight hundred million rupiah) Subsidized work training for 3 (three) months. For the prosecutor's demands, only one day later, on July 19, 201 the judge handed down a sentence of imprisonment for 6 months in prison and work training for 3 (three) months, after the verdict the Child Rape Victim remained detained;

Law is a process and justice is a result. To determine the perfection of the functioning of the law and the achievement of justice can not be separated from various kinds of contexts and circumstances. However, what always remains undeniable as the basis of law and justice is the fact that both are linked to the idea of a state to create a feeling of security and justice for every citizen $^{18}$.

Sudikno Mertokusumo argues that in enforcing the law there are 3 (three) elements which must always be considered and in enforcing the law there must be a compromise between the three elements, namely: (1) Legal Certainty; (2) Legal Benefits and; (3) justice ${ }^{19}$. A good decision must be able to accommodate all three values, but if not, then the priority is the value of justice.

According to Sudjono Dirdjosisworo, "the judges in implementing the law are known to be 3 (three) schools, one of which is the Rechtsvinding Stream. According to this school, in carrying out its duties, the judge has what is referred to as bound freedom. Therefore, the duty of judges is to attempt Rechctvinding, which means harmonizing laws with the demands of the times. Article 4 of Law Number 48 Year 2009 concerning Judicial Power states that: "Constitutional judges and judges must explore, follow and understand the legal values and sense of justice that lives in society. In this decision the judge did not explore the values that live in the community, so that in this decision the judge did not identify the Rechtsvinding (legal

\footnotetext{
${ }^{18}$ Wulansari, Penanganan Kasus-Kasus Kekerasan Terhadap Perempuan Di Lingkungan Peradilan Umum, 112.

${ }^{19}$ Sudikno Mertokusumo, Mengenal Hukum (Yogyakarta: Liberty, 1993), 130-131.
} 
discovery ${ }^{20}$. This decision does not consider legal evidence and facts revealed at the trial, so the conclusions contained in the decision dictum are inconsistent, because they do not refer to all elements of the offense with legal facts revealed in the trial. This shows that the judge does not have a gender perspective and towards the child victims of sexual violence and women's rights to reproductive health Article 75 paragraph (3) of the Health Law and Law Number 7 of 1984. The decision did not consider the psychological condition of the victim. The panel of judges has not referred to the Supreme Court Regulation No. 3 of 2017 concerning Guidelines for Judging Women Against the Law. Therefore, based on the matters stated in the conclusion that the Decision Number 5 / Pid.Sus.Anak / 2018 / PN.Mbn does not accommodate the value of justice against children who are victims of incest rape. Furthermore, judges' decisions relating to gender issues in the WA case have not indicated gender sensitivity which is the responsibility of the state.

\section{Conclusion}

The state's obligation in fulfilling the rights of children of victims of incest rape after abortion and other rights is not obtained at all from the stage of investigation to the verdict of the district court with an indication that the child of the rape victim has been detained from the investigation to the verdict of the district court. Children of victims of incest rape in investigations experience discrimination, investigations tend not to take sides by establishing children as victims of incest rape as abortionists, regardless of the cause of the abortion. In terms of substantive justice. Court decision Number 5 / Pid.Sus.Anak / 2018 / PN.Mbn has not accommodated the value of justice for children victims of incest rape. Furthermore, judges' decisions relating to gender issues in the WA case have not indicated gender sensitivity which is the responsibility of the state in this case law enforcement.

\section{References}

David, H. Bayley. Police for the Future (Polisi Masa Depan). Jakarta: Cipta Manunggal, 1994.

Dirdjosisworo, Sudjono. Pengantar Ilmu Hukum. Jakarta: Raja Grafindo Persada, 2001.

Fadly, Fadly. “2018, Terdata 105 Kasus Kekerasan Dan Pelecehan Terhadap Anak Dan Perempuan Di Jambi." Tribun Jambi. Last modified 2018. https://jambi.tribunnews.com/2018/10/16/2018-terdata-105-kasus-kekerasan-dan-

\footnotetext{
${ }^{20}$ Sudjono Dirdjosisworo, Pengantar Ilmu Hukum (Jakarta: Raja Grafindo Persada, 2001), 161.
} 
pelecehan-terhadap-anak-dan-perempuan-di-jambi.

Fauzi'ah, Syarifah. "Faktor Penyebab Pelecehan Seksual Terhadap Anak.” Jurnal An-Nisa' IX, no. 2 (2016): 82.

Hikma, Siti. "Mengantisipasi Kejahatan Seksual Terhadap Anak Melalui Pembelajaran 'Aku Anak Yang Berani Melindungi Diri Sendiri.”’ Jurnal Sawwa 12, no. 2 (2017): 189.

Indrayana, Mohammad Tegar. "Profil Kasus Kekerasan Seksual Terhadap Perempuan Dan Anak Yang Diperiksa Di Rumah Sakit Bhayangkara Dumai 2009-2013.” Jurnal Kesehatan Melayu 1, no. 1 (2017): 9-13.

Mertokusumo, Sudikno. Mengenal Hukum. Yogyakarta: Liberty, 1993.

Moser, Caroline. Gender Planning and Development: Theory, Practice and Training. London and New York: Routledge, 2012.

Nugraha, Andi Tyas Surya. "Represi Terhadap Incest (Kajian Terhadap Kasus Di Kabupaten Aran Pandang).” Jurnal Ilmiah Sosiologi Agama 9, no. 2 (2015): 94-95.

Permana, Dany. "PSI Puji Keputusan Pengadilan Jambi Bebaskan Korban Pemerkosaan.” Tribun News. Last modified 2018. https://www.tribunnews.com/nasional/2018/08/28/psi-pujikeputusan-pengadilan-jambi-bebaskan-korban-pemerkosaan.

Probosiwi, Ratih, and Daud Bahransyaf. "Pedofilia Dan Kekerasan Seksual: Masalah Dan Perlindungan Terhadap Anak.” Jurnal Sosio Informa 1, no. 1 (2015): 30.

Retnaningrum, Dwi Hapsari. "Incest Sebagai Bentuk Manifestasi Kekerasan Terhadap Perempuan." Jurnal Dinamika Hukum 9, no. 1 (2009): 19-20.

Soeroso, Moerti Hadiati. Kekerasan Dalam Rumah Tangga Dalam Perspektif YuridisViktimologis. Jakarta: Sinar Grafika, n.d.

Supramono, Gatot. Hukum Acara Pengadilan Anak. Jakarta: Djambatan, n.d.

Sutadi, Aryanto, and et. al. Diskresi Kepolisian; Dalam Tinjauan Hukum Dan Implementasinya Di Lapangan. Jakarta: Penerbit Kompolnas, 2013.

Wulansari, Lisa, ed. Penanganan Kasus-Kasus Kekerasan Terhadap Perempuan Di Lingkungan Peradilan Umum. Jakarta: Komnas Perempuan, 2009. 